\title{
Canadian National Dairy Study: Herd-level milk quality
}

\author{
C. A. Bauman, ${ }^{* 1}$ H. W. Barkema, $†$ J. Dubuc, $\ddagger$ G. P. Keefe, $\S$ and D. F. Kelton* \\ *Department of Population Medicine, University of Guelph, 50 Stone Rd., Guelph, Ontario, N1G 2W1, Canada \\ †Department of Production Animal Health, University of Calgary, 2500 University Dr., Calgary, Alberta, T2N 1N4, Canada \\ ¥Faculté de médecine vétérinaire, Université de Montréal, 3200 rue Sicotte, St- Hyacinthe, Québec, J2S 2M2, Canada \\ $\S$ Department of Health Management, University of Prince Edward Island, 550 University Avenue, Charlottetown, Prince Edward Island, C1A 4P3, \\ Canada
}

\section{ABSTRACT}

The objective of this study was to estimate Canadian national milk quality parameters and estimate the bulk tank milk (BTM) prevalence of 4 mastitis pathogens, Staphylococcus aureus, Streptococcus agalactiae, Mycoplasma bovis, and Prototheca spp., on Canadian dairy farms. A questionnaire was sent to all Canadian dairy producers. Of the 1,062 producers who completed the questionnaire, 374 producers from across the country were visited and milking hygiene was assessed. Farmlevel milk quality data for all Canadian dairy producers was collected from the provincial marketing boards and combined with the questionnaire and farm visit data. In addition, a BTM sample was collected either during the farm visit or by the marketing board in November of 2015 and was tested for 4 major mastitis pathogens using the PathoProof Mastitis Major 4 PCR Assay (Thermo Fisher Scientific Inc., Waltham, MA). Apparent herd-level prevalence was $46 \%$ for S. aureus, $6 \%$ for Prototheca spp., 0\% for M. bovis, and 0\% for Strep. agalactiae. Due to the low prevalence of $M$. bovis and Strep. agalactiae and a lack of significant factors associated with farms testing positive for Prototheca spp., an association analysis could only be carried out for Staph. aureus-positive farms. Factors associated with Staph. aureus-positive farms were not fore-stripping cows before milking (odds ratio $=1.87$ ), milking with a pipeline system (odds ratio $=2.21$ ), and stall bases made of a rubberized surface (mats and mattresses), whereas protective factors were using blanket dry cow therapy (odds ratio $=0.49$ ) and applying a tag or visible mark on cows known to have chronic mastitis infections (odds ratio $=0.45$ ). The Canadian national production-weighted geometric mean somatic cell count was determined to be 208,000 cells $/ \mathrm{mL}$. This is the first national dairy study conducted in Canada. Par-

Received June 14, 2017.

Accepted October 25, 2017.

${ }^{1}$ Corresponding author: cbauman@uoguelph.ca ticipating farms had higher milk yield; were more likely to have a loose housing system, parlor, or automated milking system; and had lower weighted mean BTM somatic cell count than the national level. Sampling larger farms with better milk quality means the apparent prevalence of the 4 mastitis pathogens likely underestimates the true levels.

Key words: Canada, Staphylococcus aureus, somatic cell count, mastitis, milk quality

\section{INTRODUCTION}

Analyzing bulk tank milk is a convenient and inexpensive method of monitoring milk quality and the presence of some pathogens in dairy cattle herds. Measuring bulk tank milk (BTM) SCC and the ability to detect the presence of bacterial pathogens (through culture or PCR-based methods) can identify herds with a high prevalence of cows with mastitis that may be caused by equipment issues, hygiene, or both. Repeated monitoring of bulk tank samples over time can also be used to evaluate the effect of implemented management and policy changes (Cook, 2007). Usefulness of BTM SCC also increases when benchmarks are available (i.e., national provincial and herd size-specific values) as it provides further motivation for change (Ritter et al., 2017).

However, establishing an accurate national benchmark for BTM SCC is contingent on the availability of the data. In most Canadian provinces, although BTM SCC is determined on a representative sample of BTM that is picked up from each herd by the provincial marketing boards, these data are confidential and reside with the boards. Only some boards report a monthly provincial average SCC, and when they do, some report a production-weighted arithmetic mean (aSCC) whereas others report an unweighted aSCC. Therefore, it is not possible to calculate an accurate national average based on this lack of uniform data. In addition, the recent trend in the dairy industry is to calculate geometric mean BTM SCC for each herd (BTM 
gSCC) as this is less influenced by incidental spikes in SCC than arithmetic means (Schook and Ruek, 1999). Epidemiological attempts at estimating the Canadian BTM gSCC have been limited regionally (Reyher et al., 2011) or based on SCC data obtained confidentially from milk recording agencies (Olde Riekerink et al., 2010; Reyher et al., 2011). Given that only 67 to $75 \%$ (Olde Riekerink et al., 2010) of dairy farms in Canada are a DHI participant, these estimates may be biased. Calculating a true national BTM gSCC would require obtaining a complete data set of SCC from all producers which is logistically challenging and has not been available to date.

Obtaining national benchmark data on the prevalence of mastitis pathogens (Staphylococcus aureus, Prototheca spp., Streptococcus agalactiae, and Mycoplasma bovis) has also been challenging. Previous studies have either been limited by their regional nature (Olde Riekerink et al., 2006; Francoz et al., 2012), used convenience sampling (Olde Riekerink et al., 2008), or lacked representation of producers not participating in DHI (Reyher et al., 2011). The concern with these studies is that the methods used to sample herds might be subject to selection bias causing the reported values to be underestimated (Reyher et al., 2011). It has been difficult to compare these values to other countries such as the ones conducted by the National Animal Health Monitoring System (NAHMS) where national dairy studies, such as NAHMS, are conducted regularly. It therefore became a priority for the Canadian dairy industry to conduct a comprehensive national dairy study that randomly sampled a subset of producers from all regions of the country and did not rely only on accumulating production data from milk recording agencies to provide national benchmarking data. The objectives of this study were therefore to (1) estimate the national BTM gSCC, (2) determine the bulk tank prevalence of Staph. aureus, Strep. agalactiae, M. bovis, and Prototheca spp., and (3) identify factors associated with farms testing positive for these mastitis pathogens.

\section{MATERIALS AND METHODS}

\section{Questionnaire Design}

A cross-sectional study of the Canadian dairy cattle industry was conducted in 2 parts: phase I, a comprehensive questionnaire administered between March 1 and April 30, 2015, followed by phase II, a farm visit to a sub-sample of questionnaire respondents that occurred between May 10 and August 30 of the same year.

Prior to undertaking the study, a collaborative research team was assembled with representatives from the 5 veterinary colleges in Canada. The main areas of focus for the questionnaire were obtained from a Priority Assessment of Canadian dairy industry stakeholders conducted in 2014 (Bauman et al., 2016). Questions were formulated to address the top 5 management and disease priorities for each stakeholder group from the assessment and were then modified upon comparison with questions from the most recent NAHMS dairy study and consultation with Canadian dairy researchers with overlapping interests and concurrent research projects funded under the Dairy Farmers of Canada Cluster 2 initiative. The initial questionnaire was 49 pages and consisted of 242 questions. Questions were initially written in English and translated to French by a bilingual representative of a provincial dairy organization. To ensure the questionnaire was relevant, nonrepetitive, concise, and easy to understand, the questionnaire was provided to a 16-person advisory group developed for this project. The group consisted of 2 dairy producers, 1 government representative, and 1 veterinarian from each of the following regions: Western provinces [British Columbia (BC), Alberta (AB), Saskatchewan (SK), and Manitoba (MB)], Ontario $(\mathbf{O N})$, Québec $(\mathbf{Q C})$, and the Eastern provinces [Prince Edward Island (PE), Nova Scotia (NS), New Brunswick (NB), and Newfoundland (NL)].

The advisory group provided feedback with regards to questions to keep, remove, and modify to improve clarity. The feedback assisted in the final formulation of a questionnaire consisting of 189 questions on 42 pages. The questionnaire format breakdown was as follows: $76(40 \%)$ multiple-choice questions with single-answer option (14 had an open-ended text entry option), 40 (21\%) multiple-choice questions with multiple-answer option (27 had an open-ended text entry option), 26 (14\%) matrix tables, $6(3 \%)$ slider scales (participant provides their response to a question on a sliding scale), 25 (13\%) open-ended text entry, 3 (2\%) drop-down menus, and $13(7 \%)$ constant sum questions (entries must total up). At the end, participants were asked if they would participate in a farm visit if they were selected. The final version of the questionnaire was pre-tested by 5 bilingual dairy stakeholders to confirm the context of the questions was consistent in both languages. The English version of the questionnaire is available in Supplemental File S1 (https://doi.org/10 $.3168 /$ jds.2017-13336).

Ethics approval for human participants was received from each participating school: University of Calgary (REB\#14-2481), University of Guelph (REB\#14DC025), Université de Montréal (15-007-CERES-D), and the University of Prince Edward Island (REB\#6006095). The questionnaire was formatted for online use with the Qualtrics platform (https://www 
.qualtrics.com/), a Microsoft Word (Microsoft Corp., Redmond, WA) document that could be mailed to producers, or a script to allow verbal administration over the telephone. As an incentive to encourage prompt participation, the first 250 respondents received a $\mathrm{C} \$ 20$ gift card to a popular national chain of coffee shops.

\section{Participant Recruitment}

Producer contact information was obtained through the 10 provincial milk marketing boards. Every licensed dairy producer in Canada was invited to participate via a letter of invitation. To maintain the confidentiality of producers and comply with the Personal Information Protection and Electronic Documents Act, each producer was assigned a unique confidential code by the marketing board consisting of 2 letters to represent their province and a 4-digit number randomly assigned (ex. ON1234). Contact information and unique codes were deposited via a secure file transfer protocol (sttp) site set up individually for each province with a national printer (LoweMartin Group, Mississauga, ON, Canada). None of the researchers or personnel outside of the printing company had access to the contact information. The letter of invitation contained information outlining the scope of the study, the website address where the questionnaire could be accessed, a quick response code linked to the website, a toll-free number with voicemail attached where requests to complete the questionnaire over the phone or in paper, in either language, could be placed or questions answered, and a reply postcard. The postcard could be returned by mail if the producer wished to have a paper version of the questionnaire mailed out to them or to notify the research group they did not wish to participate. Nonparticipants were given the option to provide a reason for nonparticipation. Printed on the reply card was the producer's unique code and contact information, and postage was paid.

No sample size calculations were performed for the phase I questionnaire as every producer in Canada was offered the opportunity to participate. Sample size calculation for phase II was based on allowable error of $5 \%, 95 \%$ confidence, expected herd-level prevalence of $\sim 40 \%$ for common endemic diseases including Staph. aureus mastitis (Olde Riekerink et al., 2010), and the equation to estimate proportions as per Dohoo et al. (2009). This resulted in a need to visit at least 368 farms.

Producers were contacted from the pool of phase I respondents, using stratified random sampling by province and their participation in milk recording. Using the 2015 distribution of dairy farms in Canada (CDIC, 2015) and the calculated sample size requirement, it was determined that farm visits within a region (west, $\mathrm{ON}, \mathrm{QC}$, and east) would be approximately equal, and then within a province would be approximately proportional to the number of producers residing in that region and province as follows: Western Canada [BC (20), AB (20), SK (10), MB (10)], ON (120), QC (120), and Eastern Canada [NB (20), NS (20), PE (20), and NL (5)]. Numbers were slightly modified due to costs of travel in some of the remote regions and limited by the number of sampling staff per province. Within each province, farms were first selected by stratifying on enrollment within a DHIA. Canadian DHI participation is approximately 75 to $80 \%$ (CDIC, 2015); therefore, from each province nonparticipants were randomly selected first to a maximum of 20 to $25 \%$ of the provincial quota when possible, and then DHI participants were randomly selected thereafter till the number of producers needed for that province was reached. Approval from the Animal Care Committees of the University of Guelph (AUP\#3320), University of Prince Edward Island (AUP\#15-106), Université de Montréal (15-Rech-1786), University of Calgary (AC15-0048), and University of Saskatchewan (AUP\#20150037) was obtained. In total, 14 university summer students were recruited from the 5 respective veterinary schools and underwent standardized training at the University of Guelph over $3 \mathrm{~d}$. The sessions included training on farm selection, questionnaire administration, biological sample collection, and animal assessments and took place in the classroom and on farm. Three students sampled farms in Western Canada, 5 students sampled ON farms, 4 sampled QC farms, and 2 sampled farms in Eastern Canada.

\section{Data and Sample Collection}

Producers were visited once, at a time that overlapped with milking if the farm used a parlor or pipeline milking system. If the farm used an automatic milking system (AMS), the visit was scheduled at the owner's convenience. During the visit the farm underwent 7 mini-assessments of pre-weaned calves, weaned calves, breeding age heifers, lactating cows, milking protocols, sick cow/calving pen housing, and heifer/cow cleanliness and lameness evaluation. A second questionnaire consisting of 149 questions was administered to producers during the visit. The question format breakdown was as follows: 111 multiple-choice questions (74\%) with single-answer option (13 open ended with text entry option), 13 multiple-choice questions (9\%) with multiple-answer option (10 open ended with text entry option), 18 open-ended questions with text entry (12\%), 5 matrix $(3 \%)$, and 2 slider questions (1\%). Main subcategories of questions were background information 
of producer, biosecurity, antimicrobial use, calf health, down cow scenario, and the role of veterinarians.

Each farm that underwent a farm visit also provided 2 BTM samples. The first sample was collected by the research team on the day of the visit when possible or provided in November 2015 by the marketing boards. The second sample was collected in December 2015/ January 2016. For all submissions, a 50-mL sample was collected into a plastic container, a 1.5-mg tablet of the preservative bronopol (2-bromo-2-nitro-propane-1,3-diol) was added, and the vial was inverted until uniform coloration was obtained. The first batch of samples was transferred by overnight courier to CanWest DHI laboratory (Guelph, ON, Canada) where they were tested for 4 mastitis pathogens: Staph. aureus, Strep. agalactiae, Prototheca spp., and M. bovis using the PathoProof Mastitis Major 4 PCR Assay (Thermo Fisher Scientific Inc., Waltham, MA) according to manufacturer's instructions with a cut-off threshold for a positive test $\leq 37.0$. The second batch of samples was transferred to the laboratory at the University of Prince Edward Island for additional testing.

In addition to the data obtained through the producers' completion of the online phase I questionnaire and the phase II farm visit questionnaire, monthly milk production (milk yield, quota holdings), monthly milk quality (BTM SCC; as defined later), and farm demographics (barn type and milking system) data for every Canadian producer (whether they participated in phase I or phase II of the study or not at all) were obtained from each provincial marketing board for the 20-mo period January 1, 2014 to Aug 30, 2015. All non-tiestall housing (bedded packs, freestalls, and other variations) was collapsed into one category and milking system was categorized as bucket, pipeline, parlor, or AMS. If a farm had 2 systems, the system that was used to milk the majority of their lactating herd was selected.

\section{Statistical Analyses}

Data were stored in Excel (Microsoft, Redmond, WA) and statistical analyses were performed using StataIC 11.1 (StataCorp LP, College Station, TX). Mean herd size (lactating cows) for the visited herds was based on the value reported by the producer in the phase I questionnaire (April-May, 2015). All SCC calculations in this study were based on monthly BTM SCC data obtained for each anonymized producer from the provincial marketing boards for the 12 -mo period between September 1, 2014, and August 30, 2015. The provinces of $\mathrm{BC}, \mathrm{ON}$, and $\mathrm{QC}$ calculate monthly production-weighted (PW) SCC for each producer based on first multiplying milk volume by the SCC for every collection of BTM, summing these products and then dividing this total by the monthly milk volume. The provinces of $\mathrm{AB}$ and $\mathrm{MB}$ calculate monthly unweighted SCC for each producer based on an arithmetic mean of $\sim 15$ SCC tests per month, whereas SK, $\mathrm{NB}, \mathrm{NS}, \mathrm{PE}$, and NL calculate monthly unweighted SCC for each producer based on an arithmetic mean of 4 SCC tests per month. Monthly production data for each producer was also provided by the provinces. Prior to calculating the national annual PW aSCC, an annual PW aSCC was calculated for each producer. In the provinces of $\mathrm{BC}, \mathrm{ON}$, and $\mathrm{QC}$ where the monthly SCC for each producer was already PW, this annual PW aSCC was calculated as the arithmetic mean of the producer's monthly values (i.e., the monthly values were summed and divided by 12). In the provinces of $\mathrm{AB}, \mathrm{SK}, \mathrm{NB}, \mathrm{NS}, \mathrm{PE}$, and NL, where the monthly values were unweighted, the monthly production data for each producer were multiplied by their monthly SCC, summing these products and then dividing this total by the annual milk volume to calculate their annual aSCC.

Each Canadian producer's PW aSCC was subsequently summed and divided by the number of producers to calculate the national annual PW aSCC.

To calculate the national PW gSCC, an annual PW gSCC was calculated for each producer. This was accomplished by taking the $\log _{10}$ of each producer's monthly PW aSCC, determining the arithmetic mean of these values, and then exponentiating this value to the power of 10. The national annual PW gSCC was calculated as the arithmetic mean of all the producer's annual PW gSCC (i.e., summing all annual PW gSCC and dividing by the number of producers).

The variables average daily milk yield, PW gSCC, quota holdings, barn type, and milking system were used to compare the sampled farms to the overall Canadian dairy farms. Differences in mean values between all Canadian producers, phase I participants, and phase II participants were evaluated using the Student's $t$-test. Differences in means between 3 or more groups such as milking system were evaluated using one-way ANOVA and Bartlett's chi-squared statistic with Bonferroni correction for multiple comparisons. Last, z-tests were used for comparison of proportions. Significance was determined at a $P$-value $<0.05$.

Statistical analysis of the association between the dichotomous outcome of a positive bulk tank sample for any of the 4 pathogens and milk production and management practices was performed using logistic regression. The variables to be included were selected a priori based on a causal diagram constructed from previous knowledge regarding on-farm milking and management practices and farm characteristics that may be associated with either a positive bulk tank PCR, a high within-herd prevalence of IMI, or biologi- 
cal plausibility. Variables were subsequently screened and removed if they lacked variability in responses or had fewer than 250 producers answer the question. Univariate analysis was based on the Wald's tests and using a liberal cut-off $P<0.10$. Variables meeting this criterion along with their interactions were included in a multivariable logistic regression model. Final model selection was performed using backward stepwise logistic regression, assessing the effect on the odds ratio and $P$-value. Variables significant at $P<0.05$ were retained in the final model. Additionally, if confounding was present and the removal of any variable resulted in a $10 \%$ change in the estimate of another predictor, that variable was also retained in the final model. Once a tentative final model was constructed, all variables that were originally deemed nonsignificant during univariate analysis were re-entered into the model one at a time and retained if their $P$-value became $<0.05$. After the final model was determined, the Pearson chi-squared goodness-of-fit test was used to determine model fit using a cut-off of $P<0.05$. Evaluating stall base composition as a risk factor was initially done using all 8 categories in the univariate analysis. The decision was made to collapse the stall base variable to rubberized surface (rubber mat/mattress, gel, and waterbed mattresses) and nonrubberized (concrete, sand, pack, and dirt) due to the similarity in the composition of the stall base surfaces.

\section{RESULTS}

\section{Sampling Results}

A total of 11,664 active producers were identified by the 10 provincial milk marketing boards in February of 2015. Monthly data on milk yield and BTM SCC were available for 11,019 (94\%) producers and milk quota holdings data were available for 11,421 (98\%) producers. Provinces had data available on housing and milking system of 11,245 (96\%) and 11,301 (97\%) producers in their province, respectively.

Ninety-six producers who received a letter of invitation to participate replied that they did not wish to participate for the following reasons: 57 indicated a lack of time, 13 were not interested, 9 cited a personal health issue, 9 expressed general comments of disgruntlement, 5 were unable to participate for issues related to their farming operation (e.g., stray voltage), 1 cited personal issues, 1 had privacy concerns, and 1 stated the online questionnaire was too long.

In total, 1,373 producers started the questionnaire, 1,124 completed at least the section on herd characteristics and demographics, and 1,062 producers (9\%) completed the phase I questionnaire. Phase II participants were selected from the 855 phase I respondents who agreed to participate (81\%). Two provinces [NB $(17 / 20)$ and NS (18/20)] had less producers participate in phase II than expected, whereas sampling exceeded the quota in 2 provinces, ON (133) and QC (121), for a total of 374 farm visits.

Total milk yield in Canada for the 12-mo period of September 1, 2014, to August 30, 2015, was 76 million $\mathrm{hL}$, whereas the mean yield per farm was 700,555 $\mathrm{L}$ with a median of $490,184 \mathrm{~L}$ (Table 1 ). Productionweighted aSCC was 214,000 cells $/ \mathrm{mL}$, and the weighted geometric mean was 208,000 cells/mL. Mean PW gSCC was higher for tiestall farms than for farms with loose housing (Table 2). Saskatchewan and MB had highest PW gSCC, whereas $\mathrm{BC}$ and $\mathrm{NB}$ were the 2 provinces with the lowest mean PW gSCC (Table 3). A total of 622 farms would be recategorized to a lower SCC category if their annual gSCC was used rather than their annual aSCC (Table 4). At the end of 2014, 9,145 producers participated in milk recording, which results in a national proportion of $78 \%$. Phase I participants were more likely to participate in milk recording than the national level $(86 \% ; P=0.005)$. The phase II proportion was influenced by the phase II sampling protocol and cannot be interpreted.

\section{Bulk Tank Tests}

Bulk tank samples were available for 372 farms visited during the summer of 2015; 2 samples (1-BC, 1-ON) were lost in transit. Of the farms tested, 178 (94\%) tested positive for 1 mastitis pathogen, and 11 farms (6\%) tested positive for 2 pathogens (10 were positive for Prototheca and Staph. aureus; 1 farm was positive for Prototheca and Strep. agalactiae). The apparent prevalence for each pathogen at the national level was as follows: 172 (46\%) farms tested positive for Staph. aureus, 24 (6\%) farms were positive for Prototheca spp., $2(0 \%)$ farms were positive for M. bovis, and $1(0 \%)$ farm was positive for Strep. agalactiae. New Brunswick and QC were the provinces with the highest apparent Staph. aureus prevalence at 71 and $62 \%$, respectively (Table 3).

Farms with gSCC $>200,000$ cell $/ \mathrm{mL}$ had a 1.5 greater odds of testing positive on bulk tank testing for Staph. aureus $(P=0.03)$. When the gSCC cutoff was increased to 300,000 (odds ratio $=0.93$ ) or 400,000 (odds ratio $=0.61)$ cells $/ \mathrm{mL}$, no effect was detected $(P$ $=0.74$ and $P=0.24$, respectively). No association were detected between gSCC and any of the other bulk tank pathogens at any gSCC cutoff. 
Table 1. Comparison of the milk quality data (mean or proportion, and 95\% CI in parentheses) between the source population and the phase I and phase II participants in the 2015 Canadian national dairy study

\begin{tabular}{lccc}
\hline Item & All Canadian dairy producers & Phase I participant $^{1}$ & Phase II participant $^{2}$ \\
\hline No. of farms & 11,019 & 1,373 & 374 \\
Annual milk yield per farm (1,000 L) & $701(685-716)$ & $837^{3}(782-895)$ & $965^{4}(861-1,069)$ \\
BTM gSCC ${ }^{5}(1,000$ cells/mL) & $209(207-210)$ & $197^{3}(193-201)$ & $189(182-196)$ \\
Quota holdings (kg of butterfat per day) & $77.8(76.9-80.4)$ & $91.4^{4}(85.9-97.0)$ & $104.1^{4}(93.5-114.7)$ \\
Herd size (lactating cows) & Not available & $77(72-82)$ & $84(76-92)$ \\
Lactating cow housing (\%) & & & $61(59-64)$ \\
Tiestall & $69(69-70)$ & $39(35-41)$ & $47(43-53)$ \\
Loose & $31(30-31)$ & $62(59-65)$ & $53(47-57)$ \\
Milking system (\%) & $69(68-69)$ & $27(25-30)$ & $50(45-55)$ \\
Pipeline & $24(23-25)$ & $10(8-12)$ & $36(31-41)$ \\
Parlor & $7(6-7)$ & $1(0-1)$ & $14(11-18)$ \\
Automated & $1(0-1)$ & 0 \\
Bucket & & \\
\hline
\end{tabular}

${ }^{1}$ Phase 1 was a comprehensive questionnaire offered on-line, via telephone interview, or in paper form to all Canadian dairy producers.

${ }^{2}$ Phase 2 was an on-farm visit where udder hygiene and other management assessments were performed, producers completed a second questionnaire, and bulk tank milk samples were obtained.

${ }^{3}$ All phase I milk quality parameters with this superscript were significantly different from the corresponding value reported for all Canadian dairy producers.

${ }^{4}$ All phase II milk quality parameters with this superscript were significantly different from the corresponding value reported for the phase I study population.

${ }^{5}$ Production-weighted geometric mean bulk tank SCC.

\section{Factors Associated with Staphylococcus aureus}

Seventy-eight questionnaire variables from the phase I and II questionnaires were considered biologically plausible in the initial data set. After initial screening of the data set, 15 variables were removed due to lack of response or low variability. Using a cutoff of $P<$
0.10, 19 categorical and no continuous variables were significant in the univariate analysis and included in the multivariable logistical regression model (Tables 4 , 5 , and 6). When any 2 of the following variables for province, barn type, milking system, or herd size were included in the model at the same time, it caused both variables to become insignificant, which demonstrated

Table 2. Variation in production-weighted geometric mean SCC by herd-level demographics in the Canadian national dairy study conducted in 2015

\begin{tabular}{lcc}
\hline Category & No. of farms $(\%)$ & gSCC $^{1}\left(\times 10^{3}\right.$ cells $\left./ \mathrm{mL}\right)$ \\
\hline Annual milk yield $(\mathrm{L} ; \mathrm{n}=11,636)$ & $4,139(36)$ & $216^{\mathrm{a}}$ \\
Low $(<400,000)$ & $4,281(37)$ & $206^{\mathrm{ab}}$ \\
Medium $(400,000-700,000)$ & $3,216(28)$ & $201^{\mathrm{b}}$ \\
High $(>700,000)$ & $7,752(69)$ & $212^{\mathrm{a}}$ \\
Housing $(\mathrm{n}=11,245)$ & $3,493(31)$ & $199^{\mathrm{b}}$ \\
Tie-stall & $779(7)$ & $220^{\mathrm{a}}$ \\
Loose & $7,749(69)$ & $212^{\mathrm{ab}}$ \\
Milking system $(\mathrm{n}=11,301)$ & $2,712(24)$ & $195^{\mathrm{bc}}$ \\
Automated & $61(1)$ & $180^{\mathrm{c}}$ \\
Pipeline & $863(81)$ & $198^{\mathrm{ab}}$ \\
Parlor & $176(17)$ & $225^{\mathrm{ac}}$ \\
Bucket & $23(2)$ & $229^{\mathrm{bc}}$ \\
Herd size (lactating cows; $\mathrm{n}=1,062)$ & $987(86)$ & $194^{\mathrm{a}}$ \\
Small $(<100)$ & $155(14)$ & $212^{\mathrm{b}}$ \\
Medium (100-300) & & \\
Large (>300) & $474(48)$ & $202^{\mathrm{a}}$ \\
Milk recording agency member $(\mathrm{n}=1,142)$ & $513(52)$ & $188^{\mathrm{b}}$ \\
Yes & & \\
No & & \\
Milk recording agency $(\mathrm{n}=987)$ & CanWest DHI & \\
Valacta &
\end{tabular}

${ }^{\mathrm{a}-\mathrm{C}}$ Within each category, estimates with different superscripts differ.

${ }^{1} \mathrm{gSCC}=$ production-weighted geometric mean SCC. 
Table 3. Mean geometric SCC $(\times 1,000$ cells $/ \mathrm{mL})$ and herd-level prevalence of Staphylococcus aureus- and Prototheca-positive PCR tests in bulk tank milk by province in Canada

\begin{tabular}{lcccc}
\hline Province & $\begin{array}{c}\text { No. of bulk } \\
\text { tank tests (\%) }\end{array}$ & $\begin{array}{c}\text { Mean gSCC } \\
(95 \% \text { CI })\end{array}$ & $\begin{array}{c}\text { Staph. aureus } \\
\text { positive }(\%)\end{array}$ & $\begin{array}{c}\text { Prototheca } \\
\text { positive }(\%)\end{array}$ \\
\hline British Columbia & $19(5)$ & $174(168-180)$ & $2(10)$ & $2(10)$ \\
Alberta & $20(5)$ & $195(189-200)$ & $5(25)$ & $1(5)$ \\
Saskatchewan & $10(3)$ & $236(224-248)$ & $4(40)$ & $0(0)$ \\
Manitoba & $10(3)$ & $234(226-243)$ & $4(40)$ & $1(10)$ \\
Ontario & $132(35)$ & $220(217-222)$ & $52(39)$ & $8(6)$ \\
Québec & $121(33)$ & $207(205-209)$ & $75(62)$ & $7(6)$ \\
New Brunswick & $17(5)$ & $176(166-186)$ & $12(71)$ & $0(0)$ \\
Nova Scotia & $18(5)$ & $189(180-199)$ & $8(44)$ & $0(0)$ \\
Prince Edward Island & $20(5)$ & $199(189-209)$ & $8(40)$ & $3(15)$ \\
Newfoundland & $5(1)$ & $221(192-250)$ & $2(40)$ & $2(40)$ \\
Total & 372 & $208(207-210)$ & $172(46)$ & $24(6)$ \\
\hline
\end{tabular}

${ }_{\mathrm{gSCC}}=$ production-weighted geometric mean SCC.

multicollinearity. This finding is further supported by the data, where barn type, milking system, and herd size (estimated by quota holdings) varied significantly by province. Ontario and Québec contained $95 \%$ of the tiestalls, $95 \%$ of the pipeline milking systems, and had a mean quota holding per farm of $67 \mathrm{~kg}$, which was different from the 8 other provinces where $81 \%$ of farms had loose housing, $81 \%$ used a parlor or an AMS, and mean quota holdings per farm were $125 \mathrm{~kg}$. Therefore, only one of these variables was included in the final model. Milking system was selected as the variable to keep because many management changes are affected by the system used rather than by province, barn type, or herd size (Table 7). In the final model, a positive Staph. aureus bulk tank PCR was strongly associated with a pipeline milking system, not marking chronically infected mastitis cows, and not fore-stripping cows before milking during the farm visit (Table 8). During stepwise removal of the variables, mild confounding was observed between stall base (rubber: yes or no), dry cow therapy (DCT; every cow, every quarter), and milking system. Removal or addition of each of these variables caused a change of 10 to $15 \%$ change in the odds ratio of one or more of the other variables and in some cases changed the $P$-values from significant to nonsignificant. For example, without stall base and milking system in the model, the $P$-value of the DCT variable was 0.033 (odds ratio $=0.45$ ), increases to 0.057 (odds ratio $=0.49$ ) with the addition of stall base, and increases to 0.061 (odds ratio $=0.49$ ) with the addition of milking system. Therefore, the decision was made to leave all 3 variables in the model. No interactions were detected between these 3 variables and no other evidence of confounding or collinearity was identified. After evaluating the Pearson $\left(\chi^{2}=33.23 ; P\right.$ $=0.34$ ) goodness-of-fit test, there was no evidence that the model did not fit the data.

\section{DISCUSSION}

This is the first comprehensive study on udder health of the national Canadian dairy cattle herd. Previous studies have been limited to one aspect of the industry (e.g., mastitis; Reyher et al., 2011), relied on data from specific regions of the country (Reyher et al., 2011), used herds that were conveniently sampled (Olde Riekerink et al., 2008), or were limited to herds that participated in milk recording (Olde Riekerink et al., 2010) or a milk quality program (Francoz et al., 2012). The main hurdles to overcome were obtaining research

Table 4. Farm-level annual arithmetic and geometric mean bulk tank milk SCC $(\times 1,000$ cells $/ \mathrm{mL})$ for Canadian dairy farms during the 12 -mo period of September 1, 2014, to August 30, 2015

\begin{tabular}{|c|c|c|c|c|c|}
\hline SCC category & $\begin{array}{c}\text { Annual PW }{ }^{1} \text { geometric } \\
\text { mean SCC }(95 \% \text { CI })\end{array}$ & $\begin{array}{l}\text { No. of } \\
\text { farms }\end{array}$ & $\begin{array}{c}\text { Annual PW arithmetic } \\
\text { mean SCC }(95 \% \text { CI })\end{array}$ & $\begin{array}{l}\text { No. of } \\
\text { farms }\end{array}$ & $\begin{array}{l}\text { No. of farms move } \\
\text { to lower category }\end{array}$ \\
\hline$<100$ & $82(81-83)$ & 533 & $83(82-84)$ & 454 & - \\
\hline 100-199 & $156(155-157)$ & 4,745 & $157(156-158)$ & 4,492 & 79 \\
\hline $300-399$ & $334(333-336)$ & 1,273 & $336(334-337)$ & 1,438 & 188 \\
\hline$\geq 400$ & $427(417-438)$ & 46 & $431(421-440)$ & 69 & 23 \\
\hline Total & 208 & 10,781 & & 10,781 & 622 \\
\hline
\end{tabular}

${ }^{1} \mathrm{PW}=$ production-weighted.

${ }^{2}$ Number of farms that move to a lower SCC category if their annual geometric SCC is used rather than their annual arithmetic mean SCC. 
expertise in multiple areas of study, obtaining sufficient resources to conduct the study across multiple regions, and establishing a relationship of trust with all regional dairy organizations to encourage their participation and support. The collaboration of many researchers from multiple fields of study and across Canada helped provide relevant questions to each area of focus of the study. Although resources are always a limiting factor, obtaining financial support from the national dairy organization (Dairy Farmers of Canada) and the federal government (Agri-Food and Agriculture Canada) was a key factor in the success in the project. Having project approval from Dairy Farmers of Canada also provided goodwill support, which encouraged the participation of all provinces. Obtainment of the national dairy data set was the most difficult hurdle to negotiate. All commodity organizations are legally required to protect their producers' identities, which is logistically challenging in every epidemiological study. However, the use of the third-party printing organization helped overcome any privacy concerns and still provided access to the desired study population. The national printer was impartial to any region or researcher and could provide secure data drop-boxes to ensure the security of the producer contact information for the mailings. By offering the questionnaire to all producers in Canada, it provided equal opportunity for all producers to participate regardless of where they lived or any agency affiliations. Obtaining milk quality and production information directly from the provincial marketing boards has allowed accurate comparison and determination of how representative the questionnaire and bulk tank results may be.

It has been previously hypothesized that producers participating in dairy studies represent farms producing more milk of higher quality (Reyher et al., 2011) and the studies are therefore prone to selection bias. Of the farms participating in this study, milk yield in phase I participants was significantly higher than the national average $(P<0.0001)$ and phase II participants produced significantly more milk than phase I participants $(P=0.0322)$. The gSCC in phase I participants was significantly lower than the national level $(-5.7 \% ; P<$ $0.0001)$ and lower yet for phase II (-9.5\%) participants, which was significantly different from the national level $(P<0.0001)$ but not significantly different from the phase I participants $(P=0.0851)$. Therefore, although this study used random sampling, it is still likely that

Table 5. Categorical farm-level variables associated with testing positive for Staphylococcus aureus in bulk tank milk (BTM; $P<0.10$; univariate analysis; $\mathrm{n}=372$ )

\begin{tabular}{|c|c|c|c|c|}
\hline Category & $\begin{array}{l}\text { No. of } \\
\text { farms (\%) }\end{array}$ & $\begin{array}{l}\text { No. of BTM-positive } \\
\text { farms }(\%)\end{array}$ & $\begin{array}{l}\text { Odds } \\
\text { ratio }\end{array}$ & $P$-value \\
\hline \multicolumn{5}{|l|}{ Province $(\mathrm{n}=372)$} \\
\hline British Columbia & $19(5)$ & $2(10)$ & Referent & - \\
\hline Alberta & $20(5)$ & $5(25)$ & 2.83 & 0.252 \\
\hline Saskatchewan & $10(3)$ & $4(40)$ & 5.67 & 0.079 \\
\hline Manitoba & $10(3)$ & $4(40)$ & 5.67 & 0.079 \\
\hline Ontario & $132(35)$ & $52(39)$ & 5.52 & 0.026 \\
\hline Québec & $121(33)$ & $75(62)$ & 14.0 & 0.001 \\
\hline New Brunswick & $17(5)$ & $12(71)$ & 20.4 & 0.001 \\
\hline Nova Scotia & $18(5)$ & $8(44)$ & 6.80 & 0.030 \\
\hline Prince Edward Island & $20(5)$ & $8(40)$ & 5.67 & 0.048 \\
\hline Newfoundland & $5(1)$ & $2(40)$ & 5.67 & 0.142 \\
\hline \multicolumn{5}{|l|}{ Region $(\mathrm{n}=372)$} \\
\hline West & $59(16)$ & $15(25)$ & Referent & - \\
\hline Ontario & $132(35)$ & $51(39)$ & 1.89 & 0.067 \\
\hline Québec & $121(33)$ & $77(64)$ & 5.02 & $<0.001$ \\
\hline East & $60(16)$ & $31(52)$ & 3.03 & 0.005 \\
\hline \multicolumn{5}{|l|}{$\operatorname{Herd~size}^{1}(\mathrm{n}=372)$} \\
\hline$<100$ & $255(69)$ & $131(51)$ & Referent & - \\
\hline $100-300$ & $74(20)$ & $25(33)$ & 0.49 & 0.01 \\
\hline$>300$ & $43(12)$ & $18(42)$ & 0.41 & 0.57 \\
\hline \multicolumn{5}{|l|}{ Closed herd $(\mathrm{n}=366)$} \\
\hline Yes & $196(54)$ & $106(62)$ & Referent & \\
\hline No & $170(46)$ & $65(38)$ & 0.53 & 0.003 \\
\hline \multicolumn{5}{|c|}{ DHI participant $(\mathrm{n}=369)$} \\
\hline Yes & $309(84)$ & $143(46)$ & Referent & \\
\hline No & $60(16)$ & $30(50)$ & 1.15 & 0.612 \\
\hline \multicolumn{5}{|l|}{ DHIA (n = 369) } \\
\hline CanWest DHI & $162(44)$ & $53(33)$ & Referent & \\
\hline Valacta & $147(40)$ & $90(61)$ & 3.22 & 0.001 \\
\hline None & $60(16)$ & $30(50)$ & 2.04 & 0.020 \\
\hline
\end{tabular}

${ }^{1}$ Number of lactating cows. 
higher yielding and better milk quality farms are likely to participate. The consequence of this selection bias is that it can potentially underestimate the prevalence of IMI that are being detected due to the dilution by higher milk yields and the nonparticipation of farms with higher SCC and possibly higher prevalences of infection. This bias may be occurring due to the reluctance of producers with high SCC or mastitis issues (or both) to participate due to the perception that they may experience judgment or embarrassment or another as yet undetermined reason.

One other objective of conducting the national study was to capture producers who did not participate in milk recording. Previous studies had omitted these nonparticipants due to the unavailability of their production data (Olde Riekerink et al., 2008). There had been the concern that previously published gSCC may not be an accurate estimate of the national level if these nonparticipating farms differed in their milk quality. When the final mean weighted gSCC of the phase II respondents $(189,000$ cells $/ \mathrm{mL})$ in the current study is compared with the gSCC of 184,000 cells $/ \mathrm{mL}$ estimated by the Olde Riekerink et al. (2008) study, the values are similar. Although the current estimate is slightly higher, no conclusion can be made that this increase is due to the inclusion of both milk recording participants and nonparticipants or if it is associated with an increase in gSCC at the national level over time.

The overall national gSCC calculated in the current study $(208,000$ cells $/ \mathrm{mL})$ is comparable to the mean BTM aSCC of 206,500 cells/mL calculated in the most recent 2014 NAHMS study (USDA, 2016). However, contrary to the US study where the mean aSCC decreased as herd size increased, in this study, mean gSCC appeared to be highest in the largest herd size ( $>300$ cows) although this relationship was not statistically significant. Producers self-reported the size

Table 6. Categorical milking system and hygiene variables associated with testing positive for Staphylococcus aureus in bulk tank milk (BTM; $P<0.10$; univariate analysis; $\mathrm{n}=372$ )

\begin{tabular}{|c|c|c|c|c|}
\hline Category & $\begin{array}{c}\text { No. of } \\
\text { farms (\%) }\end{array}$ & $\begin{array}{c}\text { No. of BTM-positive } \\
\text { farms (\%) }\end{array}$ & $\begin{array}{l}\text { Odds } \\
\text { ratio }\end{array}$ & $P$-value \\
\hline \multicolumn{5}{|l|}{ Milking system $(\mathrm{n}=368)$} \\
\hline AMS & $51(14)$ & $22(43)$ & 1.50 & 0.222 \\
\hline \multicolumn{5}{|l|}{ Clean teats $(\mathrm{n}=331)$} \\
\hline Water or water/udderwash & $76(23)$ & $48(63)$ & Referent & \\
\hline Pre-milking teat disinfection & $175(53)$ & $78(45)$ & 0.47 & 0.008 \\
\hline \multicolumn{5}{|l|}{ Weighted gSCC (cells $/ \mathrm{mL} ; \mathrm{n}=372)$} \\
\hline$<200,000$ & $211(55)$ & $89(51)$ & Referent & \\
\hline$\geq 200,000$ & $163(44)$ & $85(49)$ & 1.50 & 0.054 \\
\hline \multicolumn{5}{|c|}{ Fore-stripping before milking (self-reported; $\mathrm{n}=355$ ) } \\
\hline Yes & $285(80)$ & $129(76)$ & Referent & \\
\hline No & $71(20)$ & $40(24)$ & 1.56 & 0.101 \\
\hline Reusable cloth towel & $111(31)$ & $36(21)$ & 0.44 & 0.001 \\
\hline No drying & $46(13)$ & $24(52)$ & 0.97 & 0.920 \\
\hline Other & $36(10)$ & $20(56)$ & 1.11 & 0.782 \\
\hline \multicolumn{5}{|l|}{ Dry with same towel $(\mathrm{n}=301)$} \\
\hline Yes & $41(14)$ & $13(32)$ & Referent & \\
\hline No & $260(86)$ & $123(47)$ & 1.87 & 0.080 \\
\hline \multicolumn{5}{|c|}{ Visually tag chronically infected cows $(\mathrm{n}=259)$} \\
\hline No & $146(56)$ & $76(52)$ & Referent & \\
\hline Yes & $113(44)$ & $41(36)$ & 0.53 & 0.014 \\
\hline \multicolumn{5}{|c|}{ Milking chronically infected cows last $(\mathrm{n}=363$ ) } \\
\hline No & $190(52)$ & $76(40)$ & Referent & \\
\hline Yes & $173(48)$ & $96(56)$ & 1.85 & 0.004 \\
\hline \multicolumn{5}{|l|}{ Blanket dry cow therapy $(\mathrm{n}=364)$} \\
\hline No & $59(16)$ & $35(59)$ & Referent & \\
\hline
\end{tabular}


Table 7. Housing variables associated with testing positive for Staphylococcus aureus in bulk tank milk (BTM; $P<0.10 ;$ univariate analysis; $\mathrm{n}=372$ )

\begin{tabular}{|c|c|c|c|c|}
\hline Category & $\begin{array}{l}\text { No. }(\%) \\
\text { of farms }\end{array}$ & $\begin{array}{c}\text { No. of BTM-positive } \\
\text { farms }(\%)\end{array}$ & $\begin{array}{l}\text { Odds } \\
\text { ratio }\end{array}$ & $P$-value \\
\hline \multicolumn{5}{|l|}{ Barn type $(\mathrm{n}=368)$} \\
\hline Loose housing & $198(54)$ & $69(35)$ & Referent & - \\
\hline Tiestall & $170(46)$ & $103(61)$ & 2.85 & $<0.001$ \\
\hline \multicolumn{5}{|l|}{ Stall base $(\mathrm{n}=372)$} \\
\hline Concrete/cement & $32(9)$ & $12(38)$ & Referent & \\
\hline Gel mattress & $1(0)$ & 0 & - & \\
\hline Waterbed mattress & $16(4)$ & $6(38)$ & 1.00 & 1.000 \\
\hline Rubber-filled mattress & $91(24)$ & $41(46)$ & 1.39 & 0.43 \\
\hline Rubber mat & $131(35)$ & $80(61)$ & 2.67 & 0.016 \\
\hline Sand & $5(1)$ & 0 & - & \\
\hline Dirt & $31(8)$ & $6(19)$ & 0.400 & 0.116 \\
\hline Pack & $65(18)$ & $27(42)$ & 1.18 & 0.703 \\
\hline \multicolumn{5}{|l|}{ Stall base $(\mathrm{n}=372)$} \\
\hline Nonrubber & $133(36)$ & $45(34)$ & Referent & \\
\hline Rubber & $239(64)$ & $127(53)$ & 2.26 & $<0.001$ \\
\hline \multicolumn{5}{|c|}{ Bedding material $(\mathrm{n}=344)$} \\
\hline Straw & $190(55)$ & $102(57)$ & Referent & \\
\hline Sand & $35(10)$ & $7(20)$ & 0.22 & 0.001 \\
\hline Sawdust & $57(17)$ & $29(51)$ & 0.89 & 0.710 \\
\hline Shavings & $62(18)$ & $23(37)$ & 0.52 & 0.031 \\
\hline
\end{tabular}

of their lactating herd on the phase I questionnaire, and on closer examination discrepancies were present. If total milk yield per farm per year (data obtained from the province) was divided by the reported herd size, at least 30 producers markedly under-reported the number of cows in their herds, as it is not feasible to yield 50,000 to 200,000 L per cow per year. Therefore, the producer-reported herd size findings in this study are not reliable and future studies should use a more reliable method of obtaining accurate herd size data.

The current apparent prevalence of Staph. aureus $(46 \%)$ in BTM is lower than the level previously detected by another Canadian study (74\%; Olde Riekerink et al., 2010 ) and other provincial studies for PE (74\%; Olde
Riekerink et al., 2006) and QC (85\%; Francoz et al., 2012). The reason for the lower prevalence in the current study is likely a result of only sampling and testing one BTM sample per farm. In the Olde Riekerink et al. (2006) study, it was demonstrated that testing BTM samples at one point in time yielded a Staph. aureus prevalence of $52 \%$, but basing herd prevalence on any 1 of 3 samples taken a week apart yielded a prevalence of $74 \%$. Shedding of Staph. aureus and other mastitis pathogens at the cow level can be cyclical (Keefe, 2012) and affected by the season and stage of lactation (Zhang et al., 2016) whereas bulk tank levels of the bacterium are affected by the composition of the cow herd at any given time (absence of chronically infected animals dur-

Table 8. Final multivariate logistical regression model of factors associated with a Staphylococcus aureuspositive bulk tank milk test in Canadian dairy herds when milking system is included in the model $(\mathrm{n}=253)$

\begin{tabular}{lccc}
\hline Category & Odds ratio & $95 \%$ CI & $P$-value \\
\hline Milking system & Referent & - & - \\
Parlor & 2.21 & $1.22-4.03$ & $<0.001$ \\
Pipeline & 1.24 & $0.49-3.14$ & 0.642 \\
Automated milking system & Referent & - & - \\
Visually tag chronically infected cows & 0.45 & $0.25-0.81$ & 0.008 \\
No & & & - \\
Yes & Referent & $1.06-3.29$ & 0.032 \\
Fore-strip before milking (observed) & 1.87 & & \\
Yes & & & 0.061 \\
No & Referent & $0.23-1.03$ & \\
Blanket dry cow treatment & 0.49 & & 0.048 \\
No & & & \\
Yes & Referent & $1.01-3.25$ & \\
Stall base: rubberized surface & 1.81 & &
\end{tabular}


ing their dry period), the dilution effect from nonclinical animals with high milk yields and the withholding of milk from clinical cases (Smith, 2008). Therefore, bulk tank tests for Staph. aureus mastitis pathogens will always be more sensitive when multiple samples are taken from a farm at different time periods, which reduces the probability of missing positive farms and more likely reflects the true prevalence. Future studies should consider collecting and testing BTM samples from the visited farms quarterly over a 12-mo period.

It can also be challenging to compare herd-level mastitis prevalence data generated from studies using different milk testing methodologies especially when comparing culture to PCR results. Milk culture typically demonstrates close to perfect specificity (Olde Riekerink et al., 2010), but imperfect sensitivity due to its reliance on the presence of live bacteria and the difficulty in growing anaerobic bacteria such as $M$. bovis in vitro (Koskinen et al., 2009). Although the PathoProof PCR multiplex used in the current study demonstrated perfect analytic sensitivity and specificity for Staph. aureus using known positive individual animal milk samples, it demonstrated imperfect sensitivity and specificity at the cow level in a field study (Cederlöf et al., 2012), and no information is currently available regarding the test performance against the reference standard of BTM culture. Further diagnostic test evaluation of the PathoProof kit at the bulk tank level is needed to be able to estimate test performance and conversely the true prevalence of these pathogens at the national level.

The prevalence determinations for $M$. bovis $(0 \%)$ and Strep. agalactiae (0\%) were similar to those previously estimated at the provincial level for PE (M. bovis, $0.7 \%$; Strep. agalactiae, 1.6\%; Olde Riekerink et al., 2006) and a little lower than those estimated for QC (M. bovis, 2.6\%; Strep. agalactiae, 6\%; Francoz et al., 2012) previously.

No national levels of Prototheca prevalence have been previously published to date. The low prevalence of M. bovis and Strep. agalactiae negated the ability to evaluate any risk factors from the questionnaire results, and no factors were associated with farms testing positive for Prototheca. However, multiple predictors were identified for farms to test positive for Staph. aureus. The final model demonstrated an association between pipeline milking systems and testing positive for Staph. aureus (odds ratio $=2.21$ ). Tiestalls have been identified previously as having a higher prevalence of mastitis and specifically Staph. aureus (Olde Riekerink et al., 2008), so this result is not unexpected. However, teasing out what the management practices within pipeline or tiestall farms that are predisposing them to test positive is what is key.
The only management factors that remained in the final Staph. aureus model with milking were not visually tagging or marking animals with chronic mastitis infections, not fore-stripping, and stall base. With contagious pathogens such as Staph. aureus, where the main reservoir is the skin of infected cows, identifying and handling chronically infected animals are important strategies to minimizing within herd transmission (Keefe, 2012). Visually identifying animals, either through the application of leg tags or topical sprays, can reduce the odds (odds ratio $=0.5$ ) of testing positive on a bulk tank test for Staph. aureus compared with those who do not, and is an important precursor to implementing other management strategies such as milking infected cows last and using a separate milking unit on these cows, especially in herds where multiple employees are involved in the milking process. It is difficult to assess the effect of marking chronically infected animals on farms using an AMS, as only $3 \%(1 / 33)$ of these producers marked animals in comparison to $42 \%$ and $54 \%$ of pipeline and parlor users, respectively.

To evaluate the association between fore-stripping and Staph. aureus bulk tank prevalence, producers were asked in the phase I questionnaire to self-report if they performed fore-stripping on their farm. This was then followed up with an evaluation by technicians of milking protocols during the phase II farm visits. Eighty percent of producers who answered the questionnaire and subsequently were visited on-farm self-reported that they fore-stripped cows before milking; however, when observed on farm, a lower percentage, 66\% (246/373), of farms actually performed this procedure. Farms that reported they fore-stripped or not were at no increased risk of Staph aureus $(P=0.10)$, but when the procedure was observed, the farms that did not fore-strip were at increased risk of Staph aureus (odds ratio = $1.87 ; P=0.03$ ). The disparity in what is said and done may be a reflection of who completed the questionnaire versus who performed the milking because $87 \%$ of the questionnaire respondents were the farm owner. Interestingly, $56 \%$ of producers who said they fore-stripped and did not $(37 / 66)$ resided in the province of $\mathrm{ON}$, with the next highest province being PE (12\%).

Although Staph. aureus is not traditionally an environmental pathogen, it has been cultured from the environment of milking cows (Capurro et al., 2010) and other studies have identified rubber or 'soft' stall bases as a risk factor (Olde Riekerink et al., 2010; Dufour et al., 2012). The association with rubber stall bases may be due to the pooling of moisture on these surfaces that cannot dissipate or are due to potential chafing of udder skin that contacts the mat or mattresses when inadequate bedding is present. Chafing/skin trauma is a well-known risk factor for teat colonization with Staph. 
aureus (Fox et al., 1991). There was the concern that stall base might be an intervening variable for milking system. Fifty-seven percent of farms with pipelines indicated they had rubberized stall bases which was different from parlors (31\%) and AMS (12\%). However, stall base only partially explained the increased odds associated with pipeline systems. Having both variables in the model decreased their respective odds ratios, yet both variables still remained significant.

Although blanket DCT is often recommended for herds battling Staph. aureus mastitis (Keefe, 2012), previous literature failed to detect an association at the individual cow level between the incidence/prevalence of mastitis and blanket DCT, which was attributed to the widespread use of DCT already (88\%; Dufour et al., 2012). The current study supports the finding that blanket DCT is still widely used (84\%), but suggests that the association between DCT and Staph. aureus may be at the BTM level.

Dry cow therapy should not be included in the final Staph. aureus model if removal is solely based on the $P$-value of 0.061 ; however, the decision was made to include it due to the presence of confounding with stall base. When stall base was not controlled for through inclusion in the final model, using blanket DCT decreased the odds of testing positive for Staph. aureus by 0.45 compared with farms that did not use blanket DCT $(P=0.03)$. On farms with nonrubberized surfaces the effect was even higher (odds ratio $=0.19 ; P=$ 0.03 ), whereas the reduction in odds was nonexistent on farms with rubberized surfaces (odds ratio $=0.7 ; P$ $=0.45)$. This may indicate that using this therapy may reduce the prevalence of this pathogen in bulk tanks on farms with cement and pack bases, but is not likely to overcome the negative effect of rubberized surfaces. Further exploration of this relationship is needed. In addition, there is also a need to determine the association between the frequent use of blanket DCT and the presence of multi-drug-resistant Staph. aureus in BTM, as reducing the presence of Staph. aureus could come at the expense of increasing the prevalence of multi-drugresistant Staph. aureus. There is a concern that as the dairy industry universally works toward reducing the overall use of antimicrobials, and in particular DCT, an increase in the prevalence of Staph. aureus mastitis may occur. This reduction in DCT use will need to be monitored closely and perhaps should proceed by first evaluating its use in herds with rubberized stall bases and then limiting access for all farms to those DCTs that contain 3rd and 4th generation cephalosporins. As always, it is preferable to correct the other underlying environmental and management factors that predispose to the transmission of this infection rather than to be dependent on treating with DCT after it has occurred.

\section{CONCLUSIONS}

The results of this study provide the first opportunity for national baseline levels of the 4 most important mastitis-causing pathogens in Canada. These reported prevalences likely underestimate the true prevalence of infection because they are based on testing BTM at one point in time, the study respondent profile of larger herds with lower gSCC in comparison to the national herd, and the unknown test performance of the PCR test on BTM. To reduce the odds of testing positive for Staph. aureus, it is recommended that producers continue to be encouraged to fore-strip and to visually mark chronically infected cows, which are management practices that can be easily implemented at minimal cost. Further investigation is needed into bedding materials that can be used in conjunction with rubber mats and mattresses to minimize the effect they may be having on Staph. aureus teat colonization. Prior to discontinuing use of blanket DCT on farms with rubberized stall surfaces, this association needs to be explored further. The success of future national studies in Canada is dependent on the provinces continuing to keep accurate, up-to-date, and accessible data sets, and on the producers continuing to voluntarily provide honest and accurate data. Study results are only as reliable as the data they are based on. The positive outcomes from this study will hopefully be encouragement for the continuation of national dairy studies in Canada.

\section{ACKNOWLEDGMENTS}

This study was supported by the Dairy Cluster 2 Research program through the Canadian Agri-Science Clusters Initiative (Dairy Farmers of Canada, Agriculture and Agri-Food Canada, Canadian Dairy Commission, and Natural Sciences and Engineering Research Council). We greatly appreciate the advice and encouragement provided by Jason E. Lombard (USDA-Plant and Health Inspection Service, Fort Collins, CO) and the support of all the Canadian dairy stakeholders that participated in this project.

\section{REFERENCES}

Bauman, C., H. W. Barkema, J. Dubuc, G. P. Keefe, and D. F. Kelton. 2016. Identifying management and disease priorities of Canadian dairy industry stakeholders. J. Dairy Sci. 99:10194-10203.

Capurro, A., A. Aspán, H. Ericsson Unnerstad, K. Persson Waller, and K. Artursson. 2010. Identification of potential sources of Staphylococcus aureus in herds with mastitis problems. J. Dairy Sci. 93:180-191.

CDIC (Canadian Dairy Information Centre). 2015. Dairy Farming in Canada. Accessed Dec. 15, 2017. http://www.dairyinfo.gc.ca/ index_e.php.

Cederlöf, S., N. Toft, B. Aalbaek, and I. Klaas. 2012. Latent class analysis of the diagnostic characteristics of PCR and conventional 
bacteriological culture in diagnosing intramammary infections caused by Staphylococcus aureus in dairy cows at dry off. Acta Vet. Scand. 54:65-72.

Cook, N. 2007. A toolbox for assessing cow, udder and teat hygiene. Pages 31-43 in 46th Annu. Mtg. Natl. Mastitis Council. Accessed Dec. 18, 2017. http://milkquality.wisc.edu/wp-content/uploads/ 2011/09/toolbox-for-assessing-cow-udder-and-teat-hygiene.pdf.

Dohoo, I., S. W. Martin, and H. Stryhn. 2009. Veterinary Epidemiologic Research. 2nd ed. VER Inc., Charlottetown, PEI, Canada.

Dufour, S., I. Dohoo, H. Barkema, L. DesCôteaux, T. DeVries, K. Reyher, J.-P. Roy, and D. Scholl. 2012. Manageable risk factors associated with the lactational incidence, elimination, and prevalence of Staphylococcus aureus intramammary infections in dairy cows. J. Dairy Sci. 95:1283-1300.

Fox, L., J. Nagy, J. Hillers, J. Cronrath, and D. Ratkowsky. 1991. Effects of postmilking teat treatment on the colonization of Staphylococcus aureus on chapped teat skin. Am. J. Vet. Res. 52:799-802.

Francoz, D., L. Bergeron, M. Nadeau, and G. Beauchamp. 2012. Prevalence of contagious mastitis pathogens in bulk tank milk in Québec. Can. Vet. J. 53:1071-1078.

Keefe, G. 2012. Update on control of Staphylococcus aureus and Streptococcus agalactiae for management of mastitis. Vet. Clin. North Am. Food Anim. Pract. 28:203-216.

Koskinen, M., J. Holopainen, S. Pyörälä, P. Bredbacka, A. Pitkälä, H. Barkema, R. Bexiga, J. Roberson, L. Sølverød, R. Piccinini, D. Kelton, H. Lehmusto, S. Niskala, and L. Salmikivi. 2009. Analytical specificity and sensitivity of a real-time polymerase chain reaction assay for identification of bovine mastitis pathogens. J. Dairy Sci. 92:952-959.

Olde Riekerink, R., H. Barkema, D. Kelton, and D. Scholl. 2008. Incidence rate of clinical mastitis on Canadian dairy farms. J. Dairy Sci. 91:1366-1377.
Olde Riekerink, R., H. Barkema, D. Scholl, D. Poole, and D. Kelton. 2010. Management practices associated with the bulk-milk prevalence of Staphylococcus aureus in Canadian dairy farms. Prev. Vet. Med. 97:20-28.

Olde Riekerink, R., H. Barkema, S. Veenstra, D. Poole, R. Dingwell, and G. Keefe. 2006. Prevalence of contagious mastitis pathogens in bulk tank milk in Prince Edward Island. Can. Vet. J. 47:567-572.

Reyher, K., S. Dufour, H. Barkema, L. Des Côteaux, T. DeVries, I. Dohoo, G. Keefe, J.-P. Roy, and D. T. Scholl. 2011. The National Cohort of Dairy Farms - A data collection platform for mastitis research in Canada. J. Dairy Sci. 94:1616-1626.

Ritter, C., J. Jansen, S. Roche, D. F. Kelton, C. L. Adams, K. Orsel, R. J. Erskine, G. Benedictus, T. J. G. M. Tam, and H. W. Barkema. 2017. Invited Review: Determinants of farmers' adoption of management-based strategies for infectious disease prevention and control. J. Dairy Sci. 100:3329-3347.

Schook, G., and P. Ruek. 1999. Geometric mean somatic cell counts: What they are; what they do. Pages $93-100$ in National Mastitis Council Inc. 38th Annual Meeting Proceedings.

Smith, B. P. 2008. Large Animal Internal Medicine, 5th ed. Elsevier Mosby, St. Louis, MO.

USDA. 2016. Dairy 2014 Milk Quality, Milking Procedures, and Mastitis on U.S. Dairies, 2014. https://www.aphis.usda.gov/animal _health/nahms/dairy/downloads/dairy14/Dairy14_dr_Mastitis .pdf.

Zhang, Z., X. Li, F. Yang, J. Luo, X. Wang, L. Liu, and H. Li. 2016. Influences of season, parity, lactation, udder area, milk yield, and clinical symptoms on intramammary infection in dairy cows. J. Dairy Sci. 99:6484-6493. 